\title{
Educational activities of the School Library of the School Teaching Centre of Basic Education of UFMG
}

\author{
Flávia Filomena Rodrigues da Mata \\ Universidade Federal de Minas Gerais \\ Brasil \\ flaviafilo@hotmail.com \\ Raquel Miranda Vilela Paiva \\ Universidade Federal de Minas Gerais \\ Brasil \\ quelvilela@yahoo.com.br
}

\begin{abstract}
Working in a school library requires a professional who combines his library science técnias with knowledge of Education. From the premise that the library is no longer an accumulation of space but now a place of dissemination of knowledge, its performance changes, is increased. Thus, in 2013, the School Teaching Centre of Basic Education Library was called to offer one GTD - WGD - Working Group Differential - for students of the second cycle of human development. The GTD is a present discipline in the curriculum of Teaching Centre. The overall objective of GTD "storytelling" was to interest students of the second cycle of human training to become storytellers. The search activity to the dictionary, with a view to enriching the vocabulary, was called "The Word is". The librarian working together with teachers demonstrates the importance of this partnership and the good achieved consequences.
\end{abstract}

Keywords: School librarians, School library, Librarians - Activities, Brazil.

\section{The School library in Brazil}

When speaking in Brazilian school library is important to consider the question of education in Brazil. Thus, the library follows the rise and the development of education in the country.

The books, as well as schools, arrived in Brazil together with the Jesuits around 1549, in Bahia. At that time the books were few and difficult to acquire, which required that the priests would use the collections of the libraries of convents for literacy. This shortage and the lack of specific books for children were obstacles to the establishment of libraries dedicated to teaching, that is, to the existence of what we now know as school library.

Still, we note that "the strength of religious colleges in the construction of school libraries 
occurred, significantly, until the end of the eighteenth century, when it begins its decline, effective in mid-nineteenth century (Silva, 2011, p. 492)".

The decadence of religious schools create the conditions necessary for the foundation of other types of schools. In this context, school libraries are formed very focused on students and create an association between children's literature and school literature. In relation the functions of education, Válio (1990) indicates that "schools have been established with the law of 10/15/1827 to teach reading, writing, arithmetic and religion, privileging the readings of the Empire Constitution and History of Brazil (Válio, 1990, p. 16)."

Also related to the creation of the first school libraries in Brazilian lands Válio (1990) points out that

"The creation of school libraries within the meaning understood today, started happening in the country with the establishment of normal schools. The first to be created was the Library of Normal School Caetano de Campos, São Paulo, on June 30, 1880 and, years later, on June 16, 1894, inaugurated the Library State Capital Gymnasium (INL, 1944) (Válio, 1990, p. 18)."

If the implementation of the first school library, with the characteristics we know today, only occurred in the late nineteenth century, discussions and reflections on this space and its functions only started from the mid-twentieth century. Making an analysis of these discussions is possible to observe changes in the concept of school library over the decades. Until the 1970s, the literature on school library consists of many manual for implementation or maintenance of these spaces. This decade brings the discussion around the school research and puts the formation of readers as library function. But in fact the schools, this space is often non-existent or poor.

The 1980s mean to the school library an increase in the debates which includes its concept and possibilities arising from new technologies. Different from the traditional concept, the library goes to show as a resource for teaching and as an alternative place for development of educational activities. However, even if the discourse on school library exalt this space, it is perceived that it is still precarious.

Conceptually, the 1990s seems to recover the concepts of earlier decades: the school search gets new enhancement, especially because of the possibilities from the Internet, and reading continues valued. The difference is that the reading acquires more than its utilitarian function, but also happens to be explored your playful side, enjoyment and pleasurable. Despite the fervent discourses in favor of school libraries, their importance still remained on paper. At this time, enough to question the need for school library, since its lack does not prevent the teaching-learning process (Silva, 2001).

From the 2000s, the discussion on information literacy brings to the library the need to change and adapt to the new model of society and citizens. While this concept and its debates have arisen in the United States even in the 1980s, only from 2000s Brazilian librarians begin to reflect on this issue. 
Information Literacy wish to move the library and insert it really as a pedagogical tool within the school. This is an alternative to change the present situation of school libraries in the country. However, the position of librarian, active in school libraries should also change. These professionals must have the challenge to prepare students for the present context, which noted an informational excess.

Thus, it is necessary to break with the notion of the library as a mere appendage of the school, making it a vital space in the process of teaching and learning, both students and the school collective (Dias \& Santos, 2004). This way "it can be considered that information literacy is a step forward in the path of the library profession in the search for more space to exercise their educational role (Campello, 2009, p. 7)."

\section{School library $x$ Education}

By analyzing the history of the school library in Brazil, as well as education, we can see changes not only at the conceptual level, but also in their functions. At the moment the school library was established like a teaching support tool, is now considered necessary for the school.

In this new scenario, the school library provides services not only to students but also to the teachers, which becomes part of the users of this space. From the premise that the library is not an accumulation of books, but now a place of dissemination of knowledge, its change of operation is accentuated.

Since the beginning of the twentieth century can be registered the state's efforts and society to eradicate illiteracy in Brazil. Of the various elaborate campaigns and programs, we can highlight Paulo Freire's efforts (late 1950s, early 1960s), which has its distinctive method of the current education yet. For Freire, the subject is part of the teaching-learning process and this new vision of the student directly affects the teaching methodology.

But Freire's view, because of the very changes in the political order, will be questioned by the military regime in post-1964 force in Brazil and as a result of the new balance of power in place, Freire's educational proposal is emptied and replaced. Thus, in the 1970s there is the replacement of a focused education in critical reflection and giving up the institution of MOBRAL.

The state creates the MOBRAL as a new attempt to eradicate the question of illiteracy in the adult population in the country. The school then goes on to have as a guideline the formation of an economically productive guy, so as to respond to market demands, and therefore considered a valuable citizen. In August 1971, Law No. 5692 proposes to reformulate the education that shall be replaced by as general objective provide the student the formation skills to enable their development for self-realization, to work and to the conscious exercise of citizenship.

Also in the 1970s enlarges the influence of capitalism, and the society is, in a forceful way, to be regulated by the market. According Frigotto (1991), Brazil, from the point of view of its economy, came late in capitalism, bringing rancidity of a patriarchal, slavocratic and conservative society. In this scenario the author explains that the idea included at that time 
was that "the pure and simple access to school would raise all Brazilians to equal competitive conditions in the market. Thereafter the problem is each (Frigotto, 1991, p. 47). "

However, the same author points out that "not MOBRAL solved the problem of illiteracy, aggravated it, not everyone had access to school and, much less, who had obtained access greater social mobility (ibid, p. 48)." That is, access to education was seen an apologetic way, as being able to save all the people, but without then this responsibility was transferred to the individual, leaving him perform the necessary change in the country.

In the context that in Brazil as previously said is characterized by the military dictatorship education takes a utilitarian function, leaving aside the humanistic education in favor of forming a qualified workforce. In light of this movement education, the school library also suffers restructuring. At this time, it becomes a center of information and culture, which should serve the school community. Law 5.692 / 71 brings elements that contribute to the debate on the school library at that time and the search for changes in its operations. At that moment there is a valuation of school research and the formation of readers as essential functions of school libraries.

The 1980s is marked by the economic crisis and political effervescence in Brazil. It is called by many the last decade, but in the educational environment, was not as negligible. The establishment of the Constituent brought political discussion to the educational environment (Frigotto, 1991). Law 7044/82 amending the Law 5692/71, however, maintains the objective of teaching four ideas considered fundamental:

- The development of the student's potential;

- Self-realization;

- Preparation for work;

- Preparation for the conscious exercise of citizenship. (Silva, 2001, p. 40-41)

As pointed out, the school library suffers an impulse in his reflections, ranging from conceptualization of space to issues of technology. It is at this time that presents itself as an alternative space for teaching and learning within the school.

By the time the school library has established itself as a tool to support teaching, became perceived as necessary to school. In this new scenario, the school library is not only positions the student service, but also the teaching staff, which is placed as part of the users of this scope.

The expansion of the use of the library by the school community expand the informational and formative opportunities for students, who until then were limited to the information contained in the textbooks. Given this reality, the practice of scholarly research is gaining ground in the debate arena. The studies about this practice show positive and negative points. The negative points, the most criticized is the fact that, generally, the school library research has become synonymous mere copy. This practice certainly does not contribute effectively to the formation of knowledge.

Another element that gained even more strength in the discussions was the question of 
reading development, more precisely, the importance of educating readers. We agree that the library is a way to guarantee citizens the right to access to reading, but the way of performing such an enterprise is not yet effective. Thus, spite of so many speeches in favor of the importance of the library, which can be seen in the 1980s is that it remains far from their ideal continuing with a poor performance.

The 1990 presents discussions in Education around the student as an individual, that is, it becomes the focus of action in order to develop their potential, their freedom, their continued learning. Finally, the student is seen and respected with its own characteristics.

Accompanying the changes of Education, the school library also has new functions. Face of this new approach to education, the library is viewed as a space that contributes to the formation of the student.

The evolution of society has brought new concepts, including the Information Society. This new society has in itself the information explosion and the necessary changes in all areas.

The information society also requires a new individual model, namely flexible people, criticism, attentive to changes, conscious of their rights and obligations, able to act in this new context. Thus we have a society with a new model citizen hat generates the need for change in the education scenario and consequently the school library. Today it is required that the individual is able to consciously select what you relevant, thus exercising, reading skills, research and selection.

This information society brings with it new educational paradigms as accents Furtado (2004)

Once one of the new paradigms of education is learning to learn; that is, acquire the ability to learn, know how to get, use and generate new information; information systems become extremely important as they may contribute to its democratization, namely to facilitate and increase their access and even more, contribute to the received information to become knowledge, improving the quality of life of citizens. (Furtado, 2004)

The new educational paradigm throws on the man responsibility for their learning, without worrying about the context in which it operates. Morin (2006) made the UNESCO request some reflections on what he calls seven knowledge necessary for the future education. Are they:

1. The blindness of knowledge: the error and illusion. You need to know what really is to know. There is a need to understand brain function, physical, mental and cultural part, seeking to have the clarity that may be incurred in error or illusion.

2. The principles of the relevant knowledge. The familiar should be designed as possible to understand global and fundamental problems, inserting partial and local knowledge. Knowledge should not be fragmented, seizing thereby the objects in context, given its complexity, as a whole. To this end, it is necessary teaching methods to establish mutual and reciprocal relations between the parties and the whole in a complex world.

3. Teaching the human condition. The human being is also complex. Also consists of 
several parts (physical, biological, psychological, cultural, social) to compose a whole, however, the education tends to study this all too piecemeal, disintegrated into disciplines. Therefore, it is necessary to reconstruct the integrity, this complex identity.

4. Teaching earthly identity. The development of planetary era begins in the sixteenth century, with the advent of communication between all continents. The global financial crisis triggered in the twentieth century points out that human beings share a common destiny.

5. Addressing the uncertainties. The sciences produce many certainties and these were followed by numerous other uncertainties. Education should prepare the student to deal with unforeseen, unexpected situations and uncertainties, making a counterpoint to the deterministic concepts of human history.

6. Teach understanding. For the development of understanding, the reform of mentality is required. It is more important to understand what causes racism, xenophobia and despises than gather and explain your symptoms. This is the most effective way in the search for peace.

7. The ethics of humankind. The human condition is at the same time, be individual / society / species. This reality evokes the twenty-first century, global citizenship, and ethics developed from the moment the individual to understand how formed and forming these three facets.

Therefore, based on the reflections of Morin (2006), thinking about education this century is to go beyond what was set before. It is more to think about the student as a repository of knowledge transmitted by the teacher. It think about the formation of terrestrial, complex and citizens living in a complex society also. Simplistic solutions, who view only one or another aspect of the problem, cannot obtain satisfactory results. These changes certainly are reflected in school libraries and reinforce the need to put the librarian to act as educator.

\section{School librarian educator}

The course of decades, the conceptual and library functions changes made the librarians would also go to work as educators and this premise must accompany these professionals. Authors such as Santos (2000) emphasize that the active librarian in the school library must match of library techniques with a social and human side.

The librarian, especially one operating in the school context, should be willing to serve as a catalyst for information, dynamically and integrated into the educational performance of teachers. As I said, this professional must master more than of library techniques, requiring some understanding of the area of Education, since they must also act as educators.

In the information society, where the information really is the center of the discussions, the school library can serve as a center for cultural dissemination, through activities such as storytelling, lectures, meeting with writers, among others (Furtado, 2004).

Also the movement of Information Literacy (Dudziak, 2003) brings reflections on the role of the library and the librarian, by changes in behavior and attitude of both, "this way, librarians need to reinvent themselves, taking a more active stance, triggering processes and organizational innovation projects, both within the library, as in the context of educational 
institutions (Dudziak, 2003, p.33). "

The research Morais (2009) demonstrates the difficulty of librarians to act as educators, since all the librarians interviewed said they were not prepared to coordinate school libraries during your undergraduate degree. The Silveira's work (2007) shows the importance given to the technical content of the librarian profession in lieu of the humanistic disciplines.

However, in a different light, Campello (2009) emphasizes there by librarians awareness of their role as educators, beyond the technical functions they need to perform. Therefore, the practice within the school context, allied to search for additional training, help to minimize the librarian performance difficulties in the educational context.

In its work in the school library, the librarian needs initially to raise awareness and gain the user. Thus, the predominant actions that attract the school community to the library and reading.

Authors like Alves (1992), Mota (2004) and Morais (2009) highlights the need for interaction between teachers and library staff, which does not always occur. This relationship would be very promising, but unfortunately is still lacking, by several factors. Among these factors we can cite the lack of knowledge on the part of teachers of the school's performance and potential library. Thus, a stereotypical and negative view of the teacher regarding this space ends up interfering with the students with the library.

Silva (2001) highlights the fact the school library, mostly just consider the student as a user, forgetting the teacher and the school community. In this process of forgetting, the library ends up away or fail to approach the teachers, which could contribute greatly to the work of both professionals.

Although the librarian has to play their role as an educator, Ellwein (2006) points out that, However, must be careful, do not confuse its function, ie having well defined who is the teacher and who is the librarian because the librarian was not prepared to be a teacher and the teacher was not prepared to be librarian. (Ellwein, 2006, p. 91)

The school librarian should be a dynamic and pro-active professional who is aware of the need for constant updating. Should also seek their insertion in the school community, partnering with teachers and showing the library's potential to aid the process of teaching and learning.

The School Teaching Center of Basic Education UFMG

The Pedagogical Center originated in old Application Gymnasium UFMG, which was founded in April 21, 1954, to comply with legal arrangements established by Decree Law No. 9053 in 1946. This Decree forced the Faculties of Philosophy Federal to maintain a school for the teaching practice of students enrolled in its Didactic courses.

From 1958 became Application School, to meet the demand of Education of valuation. At that time the courses offered: High School, Scientific, Classic and Normal. 
In 1968 the UFMG was restructured and at that time the "College of Philosophy School of Application" became "Pedagogical Centre", integrated into the "Faculty of Education of UFMG" and with the basic function of offering courses on education 1st and 2nd degrees.

From 1972, the "Pedagogical Centre" was moved to the campus of Pampulha and started to take responsibility only for the then 1 st Degree. Also started to work in our own building. At this time, begins the Technical College, which will offer professional development courses for high school.

In 1997, based on guidelines of the new Guidelines and Framework Law (LDB 9394/96), the School of 1 st degree received a new name: "Elementary School of the UFMG Teaching Centre".

In 2007, the Pedagogical Centre (CP) joined together with the Technical College (COLTEC) and the University Theatre (TU), the School of Basic Education and Professional UFMG, special unit whose charter was approved by the University Council of the University Federal of Minas Gerais by Resolution No. 05/2007 of 03 May 2007.

To suit the legislation, since 2006, the elementary school is offered in nine (09) years and based on the Human Formation Cycles (this one from 1995). The entrance to the school is made by lottery.

As the school itself, its objectives are:

- Teach the elementary school, taking it as a basis for the production of investigative knowledge, education and research.

- Constitute itself as field of reflection and research on pedagogical practice.

- Constitute itself as space of new pedagogical experiments, that support progress and reflection on educational practice.

- Place for holding internship for students of Degree and Graduation.

The GTD and the library

With the conceptions of school library, with the premise of the teacher librarian role and being in a school with the philosophy of the Pedagogical Centre in 2013, the library was called to offer a GTD (Group Differentiated Work) for students of the second cycle of human development.

The GTD is a discipline included in the curriculum "Teaching Centre". This is the formation of a group of students from the diagnosis of their training requirements, aiming to make possible the expansion of this curriculum. Search respect the pace, time and experience of each student.

Just as the school teachers who offer GTD, one of the school librarians conducted the work with a group, performing systematic monitoring. In a collective work with teachers, the librarian participated in the planning, coordination and definition of the group to be assisted. Was proposed to draw up a GTD Library to teach students the art of storytelling. The aim 
was to form storytellers among the students of the second cycle of human, that is, students between 9:11 years old or so.

The methodology used included the weekly meetings with students, totalling 60 hours during the semester. The works were developed with the child and youth literature books that treat or bring legends of Brazilian folklore, rhymes, riddles and tongue-twister. It was organized also a literary contest, where the characters and authors of children's books were worked.

Experiments were done with drama, recitations and retellings of the stories, written and oral forms. It was also developed research activity in the dictionary with the goal to enrich the vocabulary. This activity was called "The Word is".

At the end of the semester was made the evaluation of GTD with students as well as teachers of that cycle. The evaluation and the exchange of information was made at a meeting. In the final evaluation, was appointed the individual student progress and of each in relation to the working group.

\section{Conclusions}

The school library assumes, from the 1980s in the United States, and 2000 in Brazil, its more proactive and integrated into the teaching process. The assumptions of information literacy bring to the practicing librarian in this space the need to re-invent and take an educational role. This role is best played when it is integrated into the education program and in partnership with the school staff.

In the Pedagogical Centre for Basic Education UFMG, the discipline of GTD intended to be a time of expansion of the students' knowledge of training, according to their needs and interests. So the role of the library at this time demonstrates its interaction with the school's goals where it belongs and also the possibilities of training of students within that space. The school's invitation to a librarian to take responsibility for a group of students shows the recognition of that school's educational professional role and potential of the library as an alternative space for student education.

The librarian working together with teachers demonstrates the importance of this partnership and the good achieved consequences. Finally, the study demonstrates the importance of effective use of library space, the acting professional in the same and their collections, which are devoted to the service of the students' knowledge of training.

\section{References}

Alves, M. C. (1992). A integração bibliotecário-professor no Brasil: o estado da arte. Dissertação (Mestrado), Faculdade de Biblioteconomia, Pontifícia Universidade Católica De Campinas, Campinas-SP, Brasil.

Campello, B. S. et al. (2007). Literatura sobre biblioteca escolar: características de citações de teses e dissertações brasileiras. Transinformação. v. 19, n. 3, p. 227-236.

Campello, B. S. (2009) Letramento informacional no Brasil: práticas educativas de bibliotecários em escolas de ensino básico. Tese (Doutorado em Ciência da 
Informação). Escola de Ciência da Informação, Universidade Federal de Minas Gerais, Belo Horizonte-MG, Brasil.

Dias, M. C. P. A.; Santos, L. V. M. (2004). Desenvolvimento do acervo das bibliotecas da rede municipal de ensino de Belo Horizonte. In: Anais Do Segundo Seminário Biblioteca Escolar Espaço De Ação Pedagógica, Belo Horizonte-MG, Brasil. Retrived 15 may 2008, from http://gebe.eci.ufmg.br/downloads/309.pdf

Dudziak, E. A. (2003). Information literacy: princípios, filosofia e prática. Ciência da Informação, v. 32, n. 1, p. 23-35.

Ellwein, S. A. F. (2006). Pesquisa escolar e o enfadonho exercício de cópia: como separar o trigo do joio. In: Silva, R. J. \& Bortolin, S. (Org.). Fazeres cotidianos da biblioteca escolar. São Paulo: Polis.

Frigotto, G. (1991). O contexto sócio político brasileiro e a educação nas décadas de 70/90. Contexto e Educação, year 6, n. 24, p. 43-47.

Furtado, C. (2004). A biblioteca escolar brasileira no sistema educacional da sociedade da informação. In: Anais Do Segundo Seminário Biblioteca Escolar Espaço De Ação Pedagógica, Belo Horizonte. Retrived 15 may 2008, from: http://www.eci.ufmg.br/gebe/downloads/317.pdf

Morais, E. M. C. (2009) Impasses e possibilidades da atuação dos profissionais das bibliotecas da Rede Municipal de Belo Horizonte. Dissertação. (Mestrado em Educação). Faculdade de Educação, Universidade Federal de Minas Gerais, Belo Horizonte, Brasil.

Morin, E. (2006). Os sete saberes necessários à educação do futuro. (11ª) São Paulo: Cortez \& Brasília: Unesco.

Mota, F. R. L. (2004). Bibliotecários e professores no contexto da biblioteca escolar: uma interação possível e necessária. In: Anais Do Segundo Seminário Biblioteca Escolar Espaço De Ação Pedagógica, Belo Horizonte-MG, Brasil.

Santos, C. A. S. \& Santos, M. P. (2013). A atividade de "indicação de leitura" realizada na IFSP: promoção de práticas de incentivo à leitura. Bibl. Esc. em Rev., v. 2, n. 1, p. 55-68.

Silva, J. L. C. (2011). Perspectivas históricas da biblioteca escolar no Brasil e análise da lei 12.244/10. Revista ACB: Biblioteconomia em Santa Catarina, v.16, n.2, p. 489517.

Silva, M. A. (2001). Biblioteca escolar e professor: duas faces da mesma moeda? Investigação sobre a interação entre a biblioteca escolar e o professor do ensino fundamental na Rede Municipal de Ensino. Dissertação (mestrado) - Escola de 
Ciência da Informação, Universidade Federal de Minas Gerais, Belo Horizonte, Brasil.

Silveira, F. J. N. (2007) Biblioteca como lugar de práticas culturais: uma discussão a partir dos currículos de Biblioteconomia no Brasil. Dissertação (Mestrado em Ciência da Informação) - Escola de Ciência da Informação Universidade Federal de Minas Gerais, Belo Horizonte, Brasil.

Soares, L. V. O. (2014). A formação como aliada no exercício do papel educativo do bibliotecário na escola. Dissertação (Mestrado em Ciência da Informação) Escola de Ciência da Informação, Universidade Federal de Minas Gerais, Belo Horizonte, Brasil.

Válio, E. B. M. (1990). Biblioteca escolar: uma visão histórica. Transinformação, v. 2, n. 1, p. 15-24.

\section{Biographical notes}

Flávia Filomena Rodrigues da MATA has worked as library school on Federal University of Minas Gerais. Master's Degree in Education from PUC-Minas. It storyteller. Teaches courses and workshops on the subject and had recurring roles in the Hall of Books and Literature Meeting sponsored by the Mining Book Council and Municipality of Belo Horizonte. Work and study on Belo Horizonte, Minas Gerais, Brazil.

Raquel Miranda Vilela PAIVA, PhD student in Information Science from the ECI / UFMG. Master in Information Science from the School of Science at UFMG info (2009). Graduated in Library Science from the Federal University of Minas Gerais (2006) and a degree in Social Empowerment Communication in Advertising in the Belo Horizonte University Center - UniBH (1999). Doing broad post-graduation, specialization Readers Training. He is currently a librarian Information Officer, Federal University of Minas Gerais, the Pedagogical Centre. Areas of interest: school library, study users, literacy and information literacy. 